\title{
Where and How Do Swiss and Foreigners Live? Segregation in the Geneva and Zurich Housing Markets
}

Caroline Schaerer and Andrea Baranzini

Cahier : N ${ }^{\circ}$ HES-SO/HEG-GE/C--08/11/1--CH

2008 


\title{
Where and How Do Swiss and Foreigners Live? Segregation in the Geneva and Zurich Housing Markets
}

\author{
Caroline Schaerer and Andrea Baranzini
}

Cahier de recherche

\section{October 2008}

\begin{abstract}
In this paper, we measure with a series of standard indicators the degree of residential segregation of the Swiss and foreign population in the urban canton of Geneva and the city of Zurich. We show that there is relatively little segregation, but that the education level (as a proxy for the socio-economic status) should be taken into account. We also compare the quality of the dwellings and neighbourhoods in which the Swiss and the foreigners live. As a general result, foreigners enjoy lesser residential comfort, but the differences are relatively small. In companion papers, we show that the lesser comfort is not fully compensated by lower rents.
\end{abstract}

\section{Keywords:}

Residential segregation; rental market; dissimilarity index; exposure index

\section{Acknowledgements}

We are grateful for financial support from the Swiss National Science Foundation, National Research Programme NRP 54 "Sustainable Development of the Built Environment". We thank the Swiss Federal Statistical Office for providing the data of the 2000 Swiss Population Census; the Geneva and Zurich Cantonal Offices for protection against noise for the noise data; the Information System of the Geneva Territory (Système d'Information du Territoire Genevois, SITG) and the Zurich GIS-centre of the office of land use regulation and measurement (GIS-Zentrum des Amtes für Raumordung und Vermessung des Kantons Zürich, ARV) for providing the GIS data. We thank Philippe Thalmann and José Ramirez for helpful remarks in a previous version of the paper. A special thank to Eva Robinson for excellent assistance support in calculating GIS variables. The usual disclaimer applies. 


\section{Introduction}

Residential segregation and discrimination has been extensively studied in countries like the United States, which exhibits a large proportion of some minorities, often very concentrated in well-defined areas. In Western Europe, the problem of ghettos in which more than 70 per cent of the area's inhabitants are of a minority group is scarcer. In fact, Western European countries often comprise a mix of different minority populations (see Huttman, 1991; Harrison et al., 2005). In Switzerland, the share of foreigners amounts to about one-fifth of total population, which makes it one of the OECD countries with the highest proportion of foreigners. Foreign population is however quite unevenly distributed over the Swiss territory, with the highest proportions being located in the urban Cantons. In 2006, the share of foreign population ranges from a maximum of 37.3 per cent in the Geneva Canton to a minimum of 8.5 percent in the Canton of Uri (OFS, 2006). In addition, the composition of resident foreign population varies according to the regions of Switzerland and is often related to the different linguistic regions of the country. Broadly speaking, relatively more foreigners from a Latin speaking country are located in the French part of Switzerland, while residents from German speaking countries and ex-Yugoslavia are more represented in the central and oriental part of Switzerland. Finally, Italian individuals are mostly present in the Italian part of Switzerland (see Huissoud et al., 1999a, for a description of the distribution of foreign population in the different regions of Switzerland). Schuler (1999) explains that since 1950, Switzerland has experienced two periods of high immigration flows, the first from 1958 to 1967, and the second during the 1980s. In both migration waves, immigrants can be distinguished based on their origin and social category. On the one side, those from Western and Northern European countries, with a relatively high education level, and on the other side, the migrants from Southern European countries, and lately from ex-Yugoslavia and Turkey, with comparatively lower socio-economic characteristics. Schuler (1999) specifies that immigration in Switzerland has been highly influenced by foreign policy measures like for e.g. delivery of residential permits and cantonal immigration quotas. With respect to the international literature, which mostly refers to the US, our approach has therefore to account for several peculiarities of the Swiss migration flows and foreign population, such as diversity of origin, education level or type of residential permit.

In spite of the political debates about the presence of foreigners and related policy migration in Switzerland, at our knowledge, the literature on residential segregation is relatively scarce, even at a descriptive level. For instance, using the 1990 Swiss Population Census, Huissoud et al. (1999) study segregation in major Swiss urban areas, among which Geneva and Zurich. Heye and Leuthold (2004) analyze residential segregation in the city of Zurich and its agglomeration. However, they are primarily concerned with the dynamics of migration in urban areas in relation to the socio-cultural neighbourhoods.

In addition to measuring segregation, a few studies highlight the residential conditions of specific population groups, as mentioned by Wanner, 2004. For instance, based on the 1980 Swiss Population Census, Arend (1991) shows that some underprivileged guest workers (Italians, Spaniards, Yugoslavians, Turks, Portuguese, and Greeks) live in housing of poorer condition than Swiss and privileged Westerners foreigners (Germans, French, Austrians, British, Americans and Dutch). In two companion papers, we analyse the impacts of discrimination and prejudice on the Geneva and Zurich housing markets, applying the hedonic approach (see Baranzini et al., 2008; and Schaerer et al., 2008). 
In this paper, we provide for additional measures of segregation and discrimination in the Cantons of Geneva and Zurich rental markets. The structure of the paper is the following. In Section 2, we present the context and the data. In section 3, we calculate different segregation indices in order to better characterise segregation in the Cantons of Geneva and Zurich. The statistics on discrimination are discussed in Section 4. Section 5 concludes and provides for areas of future research.

\section{Context and data}

In this section we describe the canton of Geneva and the municipality of Zurich in terms of population density and socio-economic composition. Our main source of information is a detailed database from the most recent Swiss Federal Population Census 2000 by the Federal Statistical Office. This database includes information on the individuals, their household as well as on the buildings and dwellings in which they live. Concerning the individuals, it provides in particular information about the gender, the number of children, the educational attainment, and the type of job. However, the dataset does not provide information about the income and the religion. From the original database we have dropped the individuals working in international organizations due to their special status, individuals with unknown origin and with unknown education level. Note that, because in this paper we are also measuring housing and environmental conditions, we need to restrict our analysis of the canton of Zurich to the Zurich Municipality. Indeed, we use road traffic noise to assess environmental conditions, which is precisely measured only at the municipal level for Zurich. Therefore, for comparative purposes, we refer to the whole canton of Geneva (thereafter Geneva), that extends on $245 \mathrm{~km}^{2}$ with 352684 inhabitants, and to the Municipality of Zurich (thereafter Zurich), of a size of $92 \mathrm{~km}^{2}$ and 338239 inhabitants.

The proportion of foreigners in Geneva and Zurich amounts to 33 per cent and 28 per cent, respectively. Note that by "foreigner", we refer to the individual that do not possess the Swiss nationality ${ }^{1}$. As already mentioned, aside their nationality, another important characteristic differentiating individuals is of course their income level. However, since the Census does not collect data on income, we decided to focus on the achieved education level, which can be thought to be correlated with income. The Census provides quite detailed information about the education level, but we decided to differentiate individuals based on "low" vs. "high" education attainments. Individuals with low education level are defined as those who do not possess any education degree, those who just completed the compulsory school and those who completed a degree in a general cultural school or a school preparing to a professional education. Individuals with a high education attainment level are all the others, i.e. those with a secondary (e.g. training school or high school diploma) or a third degree (e.g. university diploma) education level. The proportion of individuals with low education level is almost the same in the two areas, about 30 per cent of the working age population, of which about $17 \%$ of Swiss and about $13 \%$ of Foreigners. The remaining $70 \%$ of the population who has a high education is composed by $57 \%$ of Swiss and $13 \%$ of Foreigners. Relative to the Swiss (Foreign) population only, the share of Swiss (Foreigner) of working age with a low education is about 23\% (46\%) respectively. Note that we also considered using the degree of qualification required for the occupied job as a substitute for the income level as in Huissoud

1 The Swiss nationality is acquired either by birth (children of married Swiss couples have the Swiss nationality), by adoption (foreign national child adopted by a Swiss citizen) or under a naturalisation procedure. Note that there is no restriction for holding a double nationality in Switzerland. 
et al. (1999). However, we preferred the educational attainment since the job's level of qualification is available only for the working population.

The Census allows us calculating population density and socio-economic composition of the neighbourhood at two levels of aggregation: the hectare and the districts in which the building is located. In our sample, we have 48 districts and 7322 hectares for Geneva and 12 districts and 4345 hectares for Zurich ${ }^{2}$. In Geneva, the mean population by district is 7348 inhabitants, with a standard deviation of 10647 inhabitants, while in Zurich the mean population by district is 28187 individuals, with a standard deviation of 11481 . In comparison, the mean population by hectare amounts respectively to 75 (89) inhabitants in Geneva (Zurich), with a standard deviation of 95 (144) individuals. In case population is distributed heterogeneously, performing the analysis at the hectare level is more interesting, as it allows capturing more precisely the distribution of the population (see Myers, 2004). Nevertheless, for comparison we also present the variables calculated at the district level.

Using the Census data, we have calculated the following socio-economic composition variables: i) the percentage of foreign population with respect to the whole population (i.e. including children and under working-age individuals) by district and hectare in both areas; ii) the percentage of people of low education attainments with respect to the whole working-age population (i.e. with respect of the population of at least 16 years old) by district and hectare in both areas; and iii) the percentage of foreigners with low and high education levels in the whole working-age population. Figures 2 and 3 illustrate the percentage of foreign population and of individuals with high education attainment at the district and hectare levels. As expected, we observe a greater variability of the distribution of foreign population and of high educated individuals when measured at the hectare level as compared with the district. In Figure 2, we also notice that foreign population can reach a concentration of 40 to $45 \%$ of the total population especially in the districts near the city centres. Of course, given the smaller size of the hectare, this proportion can even reach more than $60 \%$ in some hectares. See also OCSTAT (2005) for a detailed description of the relative concentration of foreigners by origin in the canton of Geneva.

2 For Geneva, we refer to the 45 municipalities that compose the canton. In addition, we have accounted for a subdivision of the municipality of the city of Geneva that is often used by the Geneva Statistical Office. Therefore, we end up with 48 districts. For Zurich, we refer to the 12 boroughs that subdivide the municipality of Zurich and which are known as the "Kreise". 
Figure 1. Percentage of foreign population by district and hectare for Geneva and Zurich
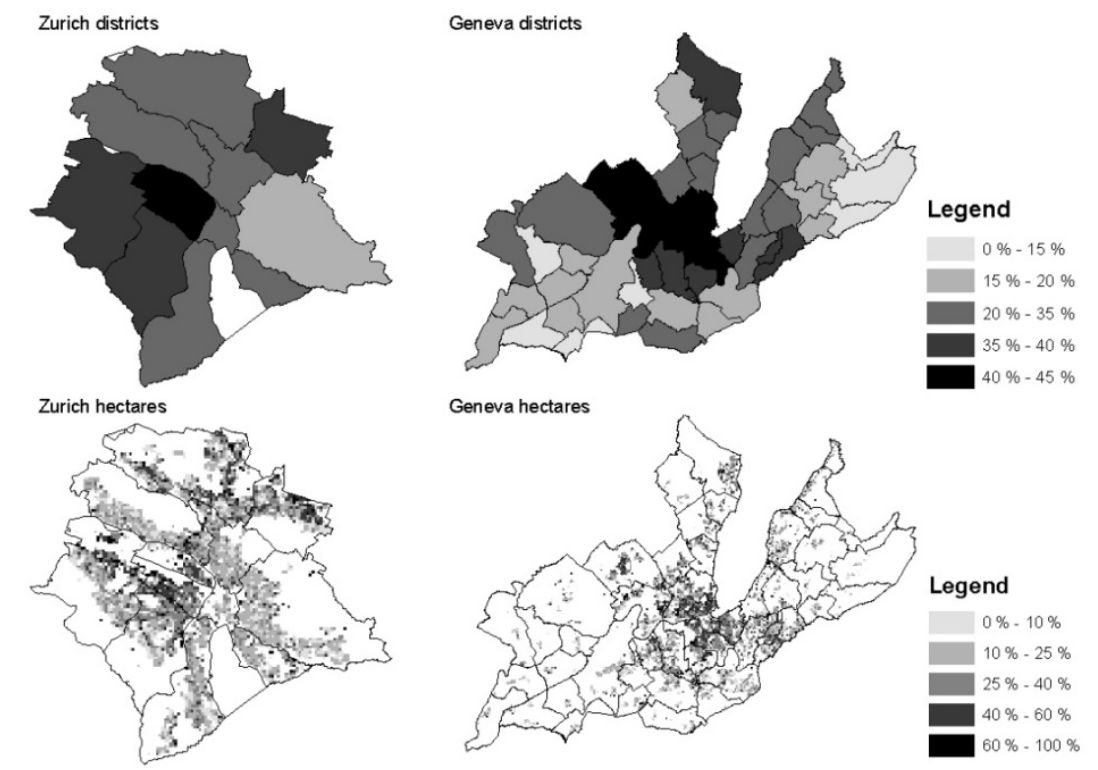

Source: Calculated using the data from Swiss Population Census 2000 (Swiss Statistical Office), from the Information System of the Geneva Territory, from the GIS-centre of the Zurich Office of land use regulation and measurement, and from the Cantonal Offices of Protection against Noise of Geneva and Zurich.

Comparing Figure 2 with Figure 3, it appears at first glance an inverse relationship between the presence of foreigners and the level of educational attainment: the higher the share of foreigners, the lower the educational attainment level. Indeed, the correlation between the share of foreigners and the share of individuals with high education level at the district level amounts to -0.91 per cent in Zurich ( -0.73 per cent in Geneva) and to -0.46 per cent at the hectare level $(-0.22$ per cent in Geneva). Such a path will be discussed in more detail in Section 3 below.

Figure 2. Percentage of individual with high education by district and hectare for Geneva and Zurich
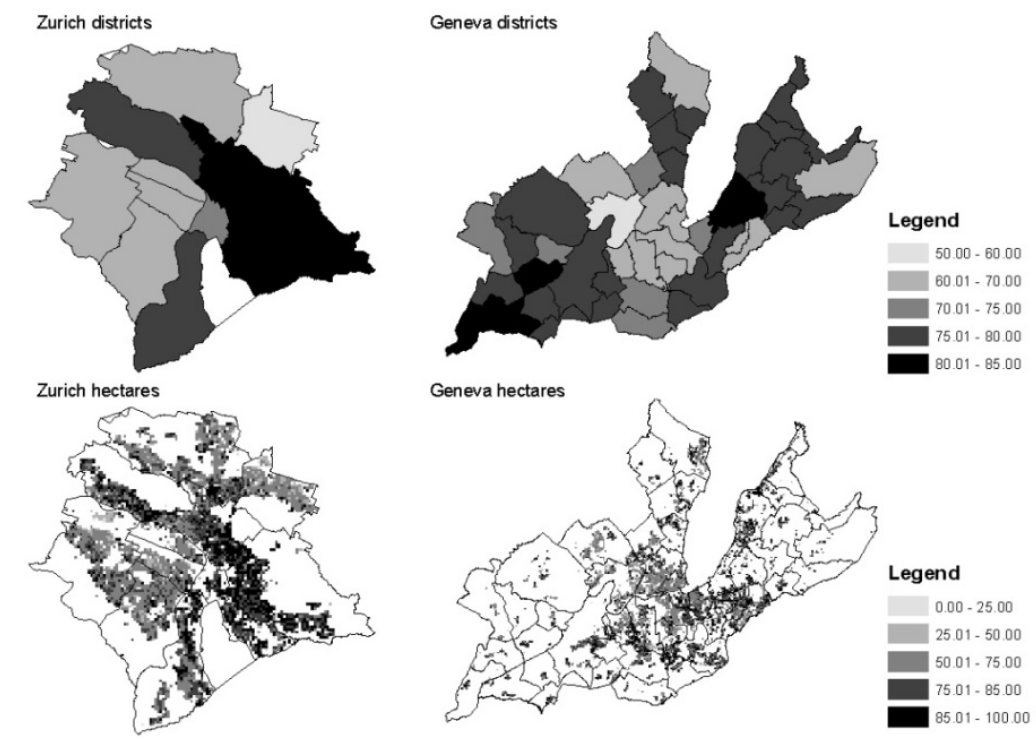

Data sources: Swiss Population Census 2000, SITG, GIS-centre of the ARV, and Cantonal Offices of Protection against Noise of Geneva and Zurich.

In order to characterise in more detail the distribution of the Geneva and Zurich population, in the next section we measure several segregation indices. 


\section{Measuring segregation: where are people living?}

The literature on residential segregation is considerable, particularly on the basis of race and ethnicity (see the influential work by Duncan and Duncan, 1955; Massey and Denton, 1988). This literature has developed measures of residential segregation by considering five different dimensions, i.e. evenness, exposure, concentration, centralization and clustering. For each of the dimensions, there exists a vast choice of segregation indices, from the single group indices, which refer to the segregation of one group with respect to the population as a whole; the two-group indices, which measure the segregation between two specified groups, to the more recent multi-group indices (see Reardon and Firebaugh, 2002). Recently, thanks to the development of the geographic information systems (GIS) technology, segregation indices have been extended in order to better account for the spatial distribution of the different groups within a city (see Reardon and O'Sullivan, 2004; Wong, 2003; Omer and Benenson, 2002). There is however little agreement on which measure should be best used in a specific context. Therefore, Massey and Denton (1988) recommend the adoption of different indices of segregation in order to account for the different facets of segregation.

In this paper, we concentrate on the two most discussed and used dimensions of segregation, i.e. evenness and exposure and we calculate aspatial indices. However, maps will describe the spatial distribution of the groups in the regions under study.

\subsection{Evenness dimension}

The evenness dimension of residential segregation refers to the distribution of one (or more) social group across the different sub-areas of a region and measures the degree of overrepresentation (underrepresentation) of this group in the region's sub-areas. Evenness is maximized when all sub-areas in the region have the same relative number of the different social groups as the region as a whole, and is minimized when no members of the different social groups share a common residential sub-area. Note that the measures of evenness depend on the relative size of the groups being compared. In this paper, we calculate the index of dissimilarity originally proposed by Duncan and Duncan (1955) and subsequently applied in the literature by e.g. Wong (2008). This index can be used to measure the residential distribution of a single group against the rest of population or of one group against another, according to the following formulas:

$$
\begin{gathered}
{ }_{x} I D_{x}=\frac{1}{2} \sum_{i=1}^{n}\left|\frac{x_{i}}{X}-\frac{t_{i}-x_{i}}{T-X}\right| \times 100 \\
{ }_{x} I D_{y}=\frac{1}{2} \sum_{i=1}^{n}\left|\frac{x_{i}}{X}-\frac{y_{i}}{Y}\right| \times 100
\end{gathered}
$$

where $t_{i}$ is the population size in sub-area $i ; x_{i}$ is the population of group $X$ members in subarea $i ; y_{i}$ represents the population of group $Y$ members in sub-area $i$; $T$ represents the population size in the region; $X$ is the population of group $X$ members in the region; and $Y$ represents the population of group $Y$ members in the region.

The dissimilarity index varies between 0 (complete evenness) and 100 (complete unevenness). In the single group case $\left({ }_{x} I D_{x}\right)$, equation (1), the index represents the proportion of group $X$ member that would have to shift location in order to achieve complete evenness. As reported in Table 1, this means that, for instance, $17.6 \%$ of the foreigners with low education level would have to move across districts in order to have complete evenness 
in their distribution in Geneva (20.2\% in Zurich). The two-group index $\left.{ }_{x} I D_{y}\right)$, equation (2), calculates the evenness distribution between two different population groups.

Table 1. Index of dissimilarity for Geneva and Zurich at the district and hectare levels

\begin{tabular}{l|cc|cc}
\hline & \multicolumn{2}{|c|}{ District } & \multicolumn{2}{c}{ Hectare } \\
\hline & Geneva & Zurich & Geneva & Zurich \\
\hline Single group index: & & & & \\
Foreigners & 13.41 & 13.75 & 30.44 & 32.90 \\
Individuals with low education & 11.13 & 14.15 & 24.51 & 25.64 \\
Individuals with high education & 8.44 & 14.19 & 20.85 & 25.34 \\
Foreigners with low education level & 17.59 & 20.17 & 35.63 & 39.56 \\
Foreigners with high education level & 10.33 & 3.67 & 23.68 & 22.89 \\
Swiss with low education & 5.92 & 6.90 & 22.07 & 23.92 \\
Swiss with high education & 7.86 & 12.67 & 21.22 & 23.58 \\
& & & & \\
Two-groups index: & & & & \\
Swiss with low education with & 14.18 & 13.42 & 36.34 & 40.44 \\
$\quad$ Foreigners with low education level & 13.01 & 7.70 & 32.27 & 33.98 \\
Foreigners with high education level & 8.44 & 11.59 & 23.32 & 26.10 \\
$\quad$ Swiss with high education & & & & \\
\hline
\end{tabular}

Data sources: Swiss Population Census 2000, SITG, GIS-centre of the ARV, and Cantonal Offices of Protection against Noise of Geneva and Zurich.

We thus observe from Table 1 that, in both Geneva and Zurich, and both at the hectare and district levels, Swiss with low education share the least common districts and hectares with low educated foreigners. On the contrary, Swiss with low education are closest to Swiss with high education level in Geneva and Zurich (and with Foreigners with high education level in the Zurich districts). From Table 1, we can conclude that the values of the dissimilarity indexes are similar in Geneva and Zurich and, as expected, the values obtained at the hectare level are higher relative to the indexes at the district level. In addition, we note that in both areas, foreigners with low education levels are the most segregated both with respect to the entire population and to Swiss people with low education level. Also based on the Swiss Federal Population Census 2000, Wanner (2004) calculates a dissimilarity index for foreigners at the level of the Zurich and Geneva agglomerations of respectively 16 and 19, which is comparable to the values reported here at the district level. In comparison to the segregation measures for US or Western European cities, the dissimilarity index between Swiss and Foreigner is very low (see e.g. Glaeser and Vidgor, 2001, for values of dissimilarity index between white and nonwhites in the major US cities; Parkinson et al., 2006, for values of the index between white and nonwhites, white and Asian and white and blacks in English cities). As emphasized by Arend (1991), the relatively small size of the Swiss cities limits the potential of segmenting population in clearly defined neighbourhoods, which might explain this relatively low level of segregation. Interestingly however, Wanner (2004) compares the evolution of the index of dissimilarity between Swiss and foreigners in 1970, 1980, 1990 and 2000 and finds a significant increase of the index, suggesting that the spatial distribution of the foreign population is less even in 2000 than it was in 1970. Note for example that in 1970 the value of the dissimilarity index for the foreigners amounted to about $12 \%$ in Zurich (respectively to about $7.5 \%$ in Geneva).

In Figure 4, we illustrate the spatial distribution of the dissimilarity index between Swiss with low education level and foreigners with comparable education attainment by district and 
hectare in Geneva and Zurich. The sum of the indexes reported in Figure 4 at the district or hectare levels corresponds to the two-group index in Table 1.

Figure 3. Dissimilarity index between Swiss with low education level and foreigners with low education level by district and hectare for Geneva and Zurich
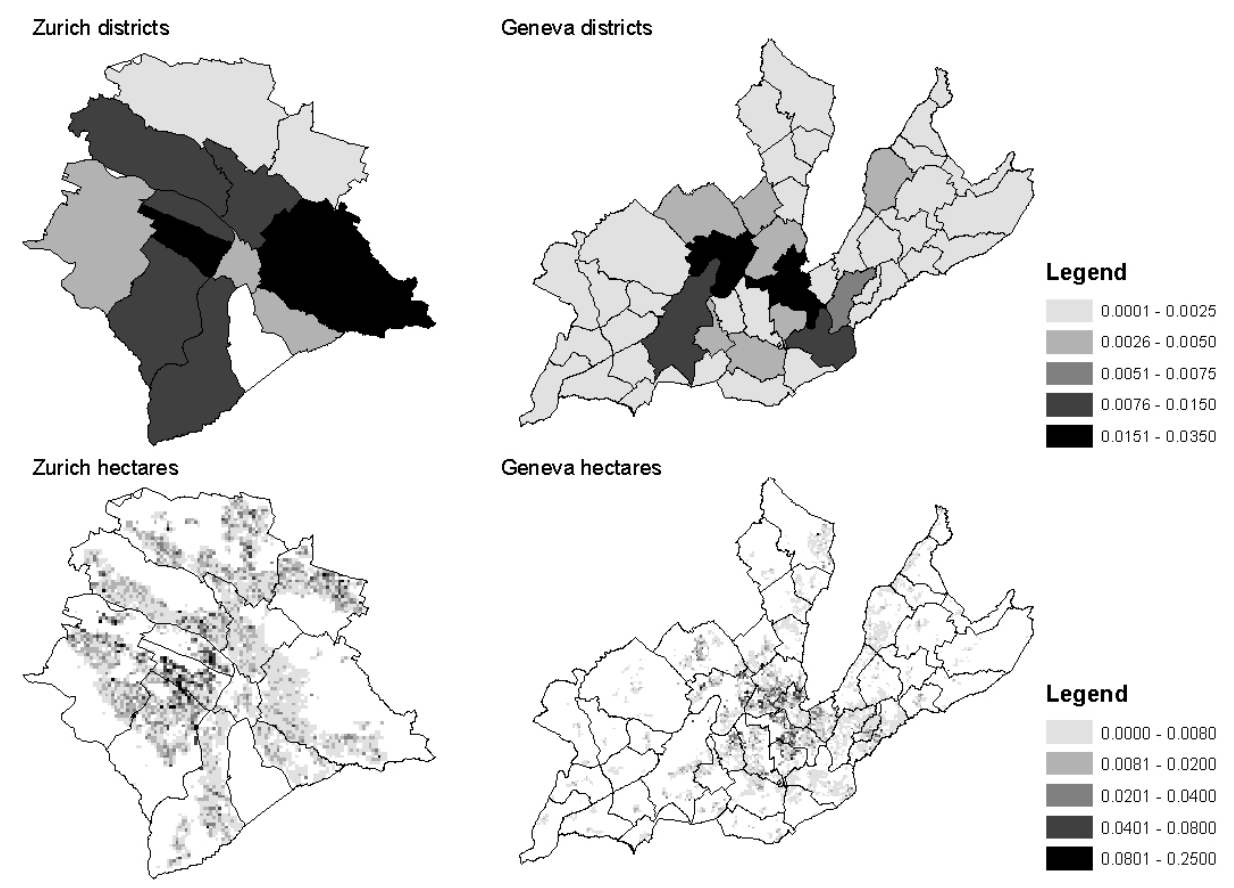

Data sources: Swiss Population Census 2000, SITG, GIS-centre of the ARV, and Cantonal Offices of Protection against Noise of Geneva and Zurich.

The figure shows that the share of foreigners with low education that would have to shift in order to achieve complete evenness with respect to the Swiss with a low education level is greater in the city centre of Geneva, respectively around the city centre in Zurich.

\subsection{Exposure dimension}

The exposure dimension of residential segregation measures the degree of potential contact, or potential interaction, between members of the same social group, or between members of different social groups, within the different sub-areas of a region. Therefore, rather than gauging segregation as departure from "evenness", exposure indices attempt to measure the experience of segregation as felt by the average minority or majority group members. Indeed, minority members can be evenly distributed among residential areas of a region, but experience little exposure to majority members. Bell (1954) proposed an exposure index that can be applied either in a single group or in two-groups case, and is calculated as follows:

$$
\begin{aligned}
& { }_{x} P{ }^{*}{ }_{x}=\sum_{i=1}^{n}\left[\frac{x_{i}}{X}\right] *\left[\frac{x_{i}}{t_{i}}\right] \times 100 \\
& { }_{x} P{ }^{*}{ }_{y}=\sum_{i=1}^{n}\left[\frac{x_{i}}{x}\right] *\left[\frac{y_{i}}{t_{i}}\right] \times 100
\end{aligned}
$$

The exposure index varies between 0 (no exposure) and 100 (complete exposure). In the single group case, equation (3), the exposure index measures the probability that a randomly drawn member of social group $x$ shares a sub-area with another member of its own social group. Thus for instance, from Table 2 we can note that in both Geneva and Zurich the individuals with the highest probability to share the same district or hectare are those with a 
high education attainment level, in particular Swiss with high education. The two-groups index, equation (4), represents the probability that a randomly drawn member of social group $x$ shares a sub-area with a member of the social group $y$. For instance, in Table 2, we see that in Geneva, the Swiss with a high education level have a probability of $41.59 \%$ of sharing the same district with Swiss individuals with low education level, of $41.45 \%$ with foreigners with high education level and of $40.01 \%$ with foreigners with low education level.

Table 2. Exposure index for Geneva and Zurich at the district and hectare levels

\begin{tabular}{l|cc|cc}
\hline & \multicolumn{2}{|c|}{ District } & \multicolumn{2}{c}{ Hectare } \\
\hline & Geneva & Zurich & Geneva & Zurich \\
\hline Single group index: & & & & \\
Foreigners & 34.73 & 29.11 & 41.79 & 37.39 \\
Individuals with low education & 26.57 & 26.84 & 31.02 & 31.05 \\
Individuals with high education & 56.20 & 62.80 & 58.93 & 65.41 \\
Foreigners with low education level & 13.72 & 12.92 & 19.61 & 19.41 \\
Foreigners with high education level & 14.62 & 11.48 & 18.68 & 14.80 \\
Swiss with low education & 13.71 & 14.82 & 17.98 & 19.36 \\
Swiss with high education & 42.38 & 51.49 & 46.18 & 54.75 \\
& & & & \\
Two-groups index: & & & & \\
Swiss with high education with & & & & \\
$\quad$ Foreigners with low education level & 40.01 & 47.61 & 34.43 & 40.44 \\
$\quad$ Foreigners with high education level & 41.45 & 50.69 & 39.18 & 48.87 \\
$\quad$ Swiss with low education & 41.59 & 49.57 & 41.15 & 48.20 \\
\hline
\end{tabular}

Data sources: Swiss Population Census 2000, SITG, GIS-centre of the ARV, and Cantonal Offices of Protection against Noise of Geneva and Zurich.

From Table 2, we can conclude that the values of the exposure index are again very similar in Geneva and Zurich. Additionally, we note that in both areas, individuals with high education levels are more concentrated. Combining the occupational status with the foreigners' nationality, Schuler and Huissoud (1999) also find a convergence between the localisation choices of the Swiss and foreigners with a high occupation level. This suggests that residential choice is driven more heavily by the occupational status than the origin. Concerning the two-group index, in both areas and at both levels, the values for the twogroup index are all very close, except for foreigners with low education level, who possess the lowest probability of sharing a hectare with Swiss people with comparable education level.

In Figure 5, we illustrate the spatial distribution of the two-group exposure index between individuals with high and those with low education level by district and hectare in Geneva and Zurich. Again, the sum of the indexes reported in Figure 5 at the district or hectare level corresponds to the two-group index in Table 2. The figure highlights more clearly that individuals with high education level are exposed to individuals with low education level only in specific parts of the areas, which corresponds to the city centre in Geneva, while more in the border in Zurich. 
Figure 4. Two-group exposure index between individuals with high education and individuals with low education level by district and hectare for Geneva and Zurich
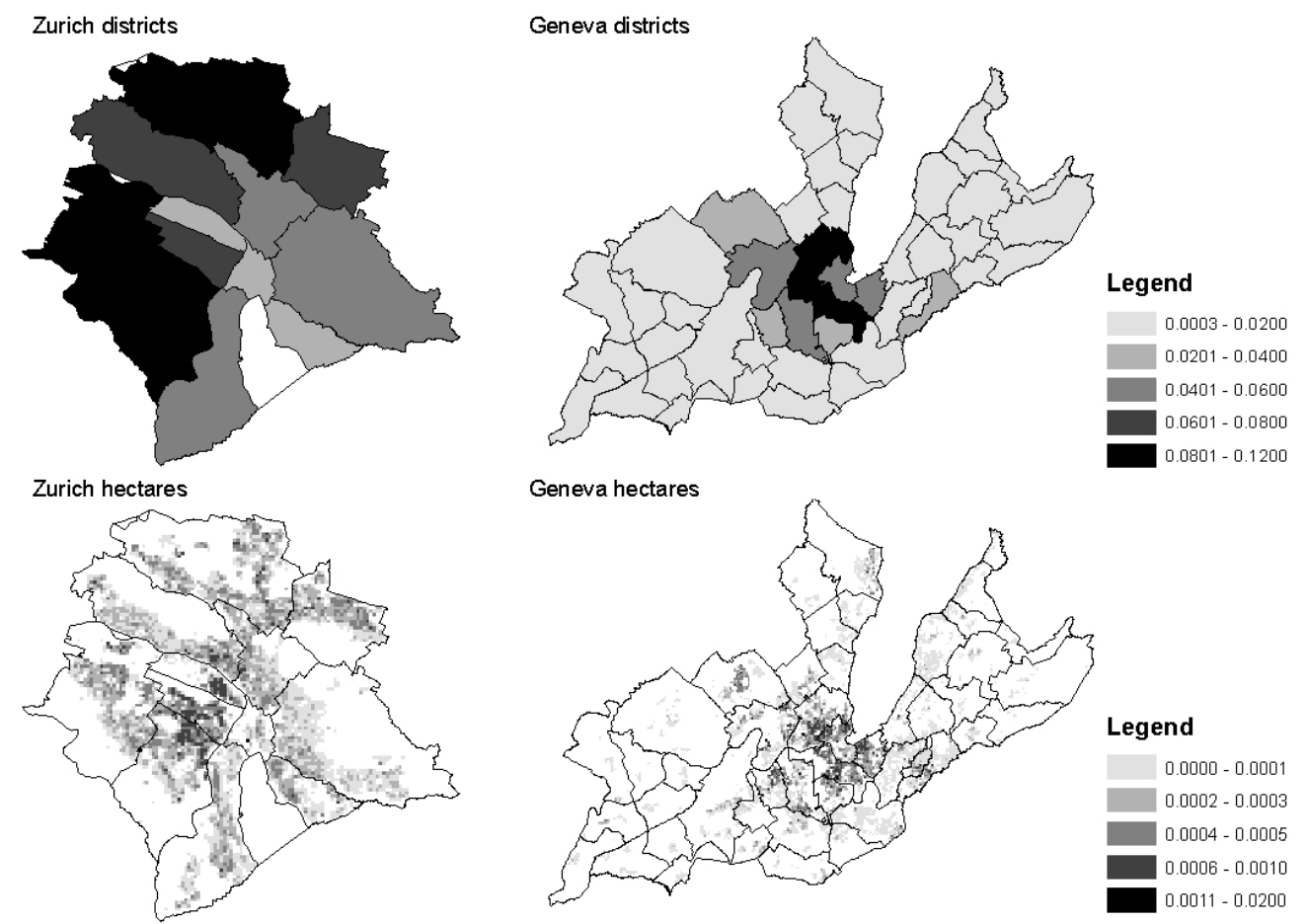

Data sources: Swiss Population Census 2000, SITG, GIS-centre of the ARV, and Cantonal Offices of Protection against Noise of Geneva and Zurich.

To further investigate the residential socio-economic environment of the individuals according to their origin and education level, in Table 3 we compare the average composition of the neighbourhoods inhabited by the different categories of individuals. We note that in Geneva, Swiss people live in a hectare that is composed on average by $71 \%$ of Swiss and $29 \%$ of foreigners, while the foreigners live in a hectare populated on average by $58 \%$ of Swiss and $42 \%$ of foreigners. Given the overall percentage of Swiss and foreigners in Geneva (i.e. $67 \%$ of Swiss and 33\% of foreigners), the over-exposure of the foreigners to other foreigners is thus equal to about $9 \%$. Values of similar magnitude are found for Zurich.

Table 3. Hectare average composition for individual of different origin

\begin{tabular}{|c|c|c|c|c|}
\hline & \multicolumn{2}{|c|}{ Geneva } & \multicolumn{2}{|c|}{ Zurich } \\
\hline & Percent Swiss & $\begin{array}{c}\text { Percent } \\
\text { foreigners }\end{array}$ & Percent Swiss & $\begin{array}{c}\text { Percent } \\
\text { foreigners }\end{array}$ \\
\hline Swiss & $\begin{array}{c}71.41 \% \\
(15.75 \%)\end{array}$ & $\begin{array}{c}28.59 \% \\
(16.22 \%)\end{array}$ & $\begin{array}{c}76.17 \% \\
(14.40 \%)\end{array}$ & $\begin{array}{c}23.83 \% \\
(14.40 \%)\end{array}$ \\
\hline Foreigner & $\begin{array}{c}58.21 \% \\
(16.22 \%)\end{array}$ & $\begin{array}{c}41.79 \% \\
(16.22 \%)\end{array}$ & $\begin{array}{c}62.61 \% \\
(17.44 \%)\end{array}$ & $\begin{array}{c}37.39 \% \\
(17.44 \%)\end{array}$ \\
\hline Overall composition & $67.06 \%$ & $32.94 \%$ & $72.43 \%$ & $27.57 \%$ \\
\hline & Swiss & Foreigners & Swiss & Foreigners \\
\hline Over-exposure to own-group & $4.35 \%$ & $8.85 \%$ & $3.74 \%$ & $9.83 \%$ \\
\hline
\end{tabular}

Standard deviation in parentheses. Data sources: Swiss Population Census 2000, SITG, GIScentre of the ARV, and Cantonal Offices of Protection against Noise of Geneva and Zurich.

The same type of comparison can be performed between individuals of different education levels. As reported in Table 4, in both areas, individuals with low education level live in a hectare that is composed on average by about $37 \%$ of individuals with the same education attainment (respectively by $63 \%$ of high educated individuals). In comparison, an individual with a high education attainment is more likely to live in a neighbourhood populated by $72 \%$ 
of individuals with high education level. Given the overall composition of low vs. high educated individuals in the two areas, the over-exposure to the own-group amounts to about $6 \%$ for the individuals with a low education level, and to about $3 \%$ for the individuals with high education level, in both Geneva and Zurich.

Table 4. Hectare average composition for individual of different education

\begin{tabular}{l|cc|cc}
\hline & \multicolumn{2}{|c|}{ Geneva } & \multicolumn{2}{c}{ Zurich } \\
\hline & $\begin{array}{l}\text { Percent low } \\
\text { education }\end{array}$ & $\begin{array}{c}\text { Percent high } \\
\text { education }\end{array}$ & $\begin{array}{c}\text { Percent low } \\
\text { education }\end{array}$ & $\begin{array}{c}\text { Percent high } \\
\text { education }\end{array}$ \\
\hline Low education & $37.71 \%$ & $62.29 \%$ & $36.05 \%$ & $63.95 \%$ \\
& $(14.11 \%)$ & $(14.11 \%)$ & $(14.80 \%)$ & $(14.80 \%)$ \\
High education & $28.54 \%$ & $71.46 \%$ & $27.13 \%$ & $72.87 \%$ \\
& $(13.06 \%)$ & $(13.06 \%)$ & $(13.55 \%)$ & $(13.55 \%)$ \\
Overall composition & $31.41 \%$ & $68.59 \%$ & $29.39 \%$ & $70.61 \%$ \\
\hline & Low education & High education & Low education & High education \\
\hline Over-exposure to own-group & $6.30 \%$ & $2.87 \%$ & $6.66 \%$ & $2.26 \%$ \\
\hline
\end{tabular}

Standard deviation in parentheses. Data sources: Swiss Population Census 2000, SITG, GIScentre of the ARV, and Cantonal Offices of Protection against Noise of Geneva and Zurich.

In Table 5 we compare the average composition of a neighbourhood inhabited by Swiss with low education level to the one inhabited by foreigners with a low education attainment. We observe that the over-exposure of foreigners with low education level to individuals of the same group amounts to about $9.5 \%$ in Geneva and to about $10.5 \%$ in Zurich.

To summarize, we observe that segregation indices are generally relatively low in Geneva and Zurich. Moreover, segregation appears to be more related to nationality than to the education level (and thus probably to income), although foreigners with low education level are those who are relatively more segregated. It should be emphasized however, that a low level of geographic concentration does not exclude that some specific groups of the population might be particularly disadvantaged in terms of living conditions. Therefore, in the next section we analyse whether there are differences in the residential conditions depending on the origin and/or the education levels.

Table 5. Hectare average composition for individuals of different origin and education level

\begin{tabular}{l|cccc|cccc}
\hline & \multicolumn{4}{|c}{ Geneva } & \multicolumn{4}{c}{ Zurich } \\
\hline & $\begin{array}{c}\text { Percent } \\
\text { Swiss low } \\
\text { education }\end{array}$ & $\begin{array}{c}\text { Percent } \\
\text { Swiss high } \\
\text { education }\end{array}$ & $\begin{array}{c}\text { Percent } \\
\text { foreigners } \\
\text { low } \\
\text { education }\end{array}$ & $\begin{array}{c}\text { Percent } \\
\text { foreigners } \\
\text { high } \\
\text { education }\end{array}$ & $\begin{array}{c}\text { Percent } \\
\text { Swiss low } \\
\text { education }\end{array}$ & $\begin{array}{c}\text { Percent } \\
\text { Swiss high } \\
\text { education }\end{array}$ & $\begin{array}{c}\text { Percent } \\
\text { foreigners } \\
\text { low } \\
\text { education }\end{array}$ & $\begin{array}{c}\text { Percent } \\
\text { foreigners } \\
\text { high } \\
\text { education }\end{array}$ \\
\hline Swiss low education & $21.35 \%$ & $49.57 \%$ & $14.14 \%$ & $14.93 \%$ & $21.94 \%$ & $54.78 \%$ & $11.92 \%$ & $11.35 \%$ \\
& $(11.77 \%)$ & $(14.13 \%)$ & $(10.92 \%)$ & $(8.31 \%)$ & $(12.58 \%)$ & $(14.89 \%)$ & $(10.55 \%)$ & $(6.42 \%)$ \\
Swiss high education & $16.03 \%$ & $56.03 \%$ & $12.06 \%$ & $15.88 \%$ & $15.70 \%$ & $61.83 \%$ & $10.02 \%$ & $12.45 \%$ \\
& $(8.26 \%)$ & $(15.15 \%)$ & $(10.09 \%)$ & $(9.05 \%)$ & $(8.47 \%)$ & $(13.58 \%)$ & $(9.62 \%)$ & $(6.50 \%)$ \\
Foreigner low education & $15.88 \%$ & $41.89 \%$ & $24.31 \%$ & $17.91 \%$ & $15.87 \%$ & $46.53 \%$ & $23.09 \%$ & $14.51 \%$ \\
& $(7.13 \%)$ & $(13.52 \%)$ & $(14.06 \%)$ & $(7.45 \%)$ & $(8.04 \%)$ & $(15.03 \%)$ & $(13.92 \%)$ & $(6.29 \%)$ \\
Foreigner high education & $14.44 \%$ & $47.47 \%$ & $15.42 \%$ & $22.67 \%$ & $14.39 \%$ & $55.08 \%$ & $13.82 \%$ & $16.71 \%$ \\
& $(6.92 \%)$ & $(13.75 \%)$ & $(11.32 \%)$ & $(12.17 \%)$ & $(7.37 \%)$ & $(15.08 \%)$ & $(11.88 \%)$ & $(8.09 \%)$ \\
Overall composition & $16.49 \%$ & $51.38 \%$ & $14.92 \%$ & $17.21 \%$ & $16.63 \%$ & $57.57 \%$ & $12.76 \%$ & $13.04 \%$ \\
\hline
\end{tabular}

Standard deviation in parentheses. Data sources: Swiss Population Census 2000, SITG, GIS-centre of the ARV, and Cantonal Offices of Protection against Noise of Geneva and Zurich. 


\section{Analysing residential conditions: how are people living?}

In order to describe the living conditions and to test for quality differentials between dwellings occupied by different categories of individuals, we need information on dwellings and buildings characteristics, as well as data measuring the neighbourhood quality, in addition to the individual socio-economic characteristics. Concerning building and dwelling characteristics, they are reported in the 2000 Swiss Population Census. However, since the same dwelling will appear more than once in the dataset for each household composed of more than one individual, we keep the household's head only. ${ }^{3}$ In order to limit the scope of our analysis, we limit it to rented apartments. From the dataset, we thus drop the owners, the members of a housing cooperative, the single family houses, and the holders of special rent contracts (i.e. holders of a free-rent dwelling, holder of service dwelling, or of a farming lease). To this dataset we add several variables in order to measure environmental and accessibility characteristics of the building and the neighbourhood.

Firstly, we add location characteristics calculated using the Information System of the Geneva Territory (SITG) and the GIS-centre of the Zurich office of land use regulation and measurement (ARV), two very rich and well-developed GIS databases. Using these datasets, we calculate accessibility variables, which measure precisely the proximity of the buildings to environmental amenities and main public infrastructures, such as the distance to the city centre, to the nearest urban park and to the nearest public transportation stop. In addition, we define several neighbourhood characteristics (at the district level) quantifying the percentage of different land-use features, such as the percentage of tree-covered area and the percentage of urban parks.

Secondly, from the Cantonal offices of protection against noise of Geneva and Zurich, we obtained the yearly averaged daytime traffic noise, expressed in the A-weighted decibel scale $(\mathrm{dB}(\mathrm{A}))$. The data refer to the level of noise caused by road traffic, measured at some fixed points, and then extrapolated for each facade of the buildings. The daytime noise level represents the equivalent continuous noise level averaged over 15 hours. Note that since noise is often measured where the road traffic noise is suspected to be high, the average noise level in our sample may overestimate the effective average noise exposure in the regions.

As a result, starting from the Census information on 352684 individuals for Geneva and 338239 individuals for Zurich, keeping only information for the household's head, merging all the information, dropping observations for which noise exposure is unreliable ${ }^{4}$, as well as a few outliers, we obtain two overall samples of 42162 observations for Geneva and of 26489 observations for Zurich. Note that these datasets are used in Schaerer et al. (2008) to value the impact of discrimination in the housing market of Geneva and Zurich.

3 The household head is defined according to the following criteria, by order of priority: 1) an older individual is preferred over a younger one; 2) a full-time working individual is selected over a part time working, an unemployed, a retired individual, an individual in an education process, or over a individual who is not in the labor force; 3) an individual occupying an executive job is chosen over an individual with an independent activity, a intermediate job, an employee, a factory worker, or an apprentice.

4 Observations for which the noise exposure lies above $75 \mathrm{~dB}(\mathrm{~A})$ are dropped because noise measures at those levels are unreliable (see acoustic literature, e.g. Miedema et al., 1998; 2001). In the same vein, we restricted our samples to the observations for which the noise levels exceeded, or equaled, $55 \mathrm{~dB}(\mathrm{~A})$ during the day. These thresholds correspond to the planning regulations for housing areas in Swiss law (see Swiss Noise Abatement Ordinance, 1986, art. 43). See Baranzini et al. (2006) for a discussion. 
To analyse whether different groups live in dwellings with different characteristics, we propose to segment the housing market according to the household head characteristics based on three criteria, i.e. the origin (Swiss vs. Foreigner), the education attainment (Low vs. High) and the origin of individuals with low education level (Swiss with low education vs. Foreigner with low education). We report the average living conditions for the three different segmentations in Table 6 for Geneva and in Table 7 for Zurich. The difference in the means for the dwelling and neighbourhood characteristics between the two sub-samples in each segment has been tested using pair-wise mean comparison tests. The means that are statistically different between the two samples are highlighted in bold in Tables 6 and 7 .

\subsection{Housing conditions in Geneva}

The segmentation by origin between Swiss households and foreign households in Geneva is presented in columns 2 and 3 of Table 6 . Most of the means for the dwelling and neighbourhood characteristics differ between the two samples. In particular, Swiss people live in comparatively larger dwellings in terms of number of rooms and surface per person, the latter being around $47 \mathrm{~m}^{2}$ per person in the Swiss sample and only $37 \mathrm{~m}^{2}$ per person in the foreign sample. OCSTAT (2005) also mention that the occupancy rate (number of persons per room) is larger for foreigners. Other differences are related to luxury characteristics of the dwelling, e.g. a lower proportion of foreigners live in an attic dwelling, while a higher proportion of them only have a small kitchen. Relatively more Swiss live in publicly owned building and less in privately owned ones. It is also interesting to note that foreigners are on average exposed to a slightly higher daily road traffic noise level $(66 \mathrm{~dB}(A))$ than the Swiss $(65 \mathrm{~dB}(\mathrm{~A}))$, both averages exceeding the legal limit of $60 \mathrm{~dB}(\mathrm{~A})$ set in the Swiss noise regulation for residential areas (Swiss Noise Abatement Ordinance 1986, art. 43). Concerning the neighbourhood composition characteristics, foreigners live on average in neighbourhoods with a relatively higher proportion of foreigners, as already discussed in the previous section.

The second sample segmentation reported in columns 4 and 5 of Table 6 is between the low and high educated individuals. Again, a clear pattern appears between the dwellings inhabited by the low vs. high educated individuals. Indeed, on average households with low education level live in higher buildings, constructed between 1946 and 1980. They live in smaller dwellings, both in terms of number of rooms and surface per room, and have a higher occupation rate of the dwelling surface. Comparatively fewer of the low educated individuals have a regular kitchen, possess gas heating and live in an attic. Interestingly, more of them live in publicly owned building and less in privately owned ones. They show a higher dwelling turnover rate, are located in higher density neighbourhoods and are more exposed to road traffic noise.

The last segmentation of interest compares the dwellings occupied by Swiss with low education level to those of foreigners with low education level. The statistics, reported in the last two columns of Table 6, shows that among the individuals with low education level, the foreigners live in dwellings of relatively worse quality. In fact, we can observe a similar pattern as with the segmentation between low vs. high educated individuals. 
Table 6. Statistics by origin and level of education of the household head for Geneva

\begin{tabular}{|c|c|c|c|c|c|c|}
\hline \multirow{2}{*}{$\begin{array}{l}\text { Segmentation } \\
\text { Sample }\end{array}$} & \multicolumn{2}{|c|}{ Origin } & \multicolumn{2}{|c|}{ Education } & \multicolumn{2}{|c|}{ Origin and education } \\
\hline & Swiss & Foreigner & $\begin{array}{l}\text { Low } \\
\text { education }\end{array}$ & $\begin{array}{l}\text { High } \\
\text { education }\end{array}$ & $\begin{array}{l}\text { Swiss: } \\
\text { Low education }\end{array}$ & $\begin{array}{l}\text { Foreigner: } \\
\text { Low education }\end{array}$ \\
\hline $\begin{array}{l}\text { Net monthly rent } \\
\text { Structural characteristics }\end{array}$ & 1087 & 1074 & 942 & 1149 & 910 & 969 \\
\hline Built between 1946 and 1960 & 0.1696 & 0.1725 & 0.1868 & 0.1629 & 0.1945 & 0.1804 \\
\hline Built between 1961 and 1970 & 0.2090 & 0.2279 & 0.2675 & 0.1913 & 0.2813 & 0.2562 \\
\hline Built between 1971 and 1980 & 0.1497 & 0.1529 & 0.1521 & 0.1503 & 0.1440 & 0.1587 \\
\hline Built between 1981 and 1990 & 0.0809 & 0.0780 & 0.0637 & 0.0875 & 0.0546 & 0.0712 \\
\hline Built between 1991 and 2000 & 0.0889 & 0.0978 & 0.0769 & 0.0996 & 0.0668 & 0.0852 \\
\hline Building was renovated before 1990 & 0.0552 & 0.0541 & 0.0498 & 0.0572 & 0.0483 & 0.0511 \\
\hline Floor level & 3.7147 & 3.3616 & 3.4126 & 3.6664 & 3.6985 & 3.1784 \\
\hline Number of floors in the building & 7.4857 & 7.4440 & 7.5281 & 7.4425 & 7.6696 & 7.4122 \\
\hline Number of rooms & 28891 & 2.8085 & 2.7138 & 2.9290 & 2.6698 & 27498 \\
\hline Surface per room [m2] & 26.5701 & 26.0806 & 25.9460 & 26.6016 & 26.3089 & 25.6489 \\
\hline Surface per inhabitant [m2] & 47.0888 & 36.7176 & 38.8165 & 45.3802 & 47.2027 & 31.9502 \\
\hline Kitchenette & 0.0318 & 0.0492 & 0.0428 & 0.0361 & 0.0388 & 0.0460 \\
\hline Attic & 0.0425 & 0.0271 & 0.0258 & 0.0420 & 0.0341 & 0.0189 \\
\hline Gas heating & 0.2397 & 0.2576 & 0.2285 & 0.2549 & 0.2035 & 0.2490 \\
\hline Privately owned building & 0.3314 & 0.3519 & 0.3237 & 0.3464 & 0.2994 & 0.3436 \\
\hline Publicly owned building & 0.0714 & 0.0426 & 0.0729 & 0.0549 & 0.1052 & 0.0464 \\
\hline $\begin{array}{l}\text { In the dwelling for at least } 5 \text { years } \\
\text { Location characteristics }\end{array}$ & 0.5887 & 0.5026 & 0.6215 & 0.5258 & 0.6798 & 0.5738 \\
\hline Distance to nearest transportation stop [km] & 0.1214 & 0.1196 & 0.1199 & 0.1211 & 0.1209 & 0.1191 \\
\hline Distance to nearest park $[\mathrm{km}]$ & 0.1217 & 0.1271 & 0.1270 & 0.1221 & 0.1239 & 0.1295 \\
\hline Distance to city centre $[\mathrm{km}]$ & 23258 & 2.2939 & 2.3508 & 2.2964 & 2.3539 & 2.3483 \\
\hline $\begin{array}{l}\text { Population density [per ha] } \\
\text { Environmental characteristics }\end{array}$ & 225.4012 & 238.4134 & 239.0909 & 225.9567 & 233.2579 & 243.8667 \\
\hline $\begin{array}{l}\text { Daytime noise }[\mathrm{dB}(\mathrm{A})] \\
\text { Household head characteristics }\end{array}$ & 65.4791 & 66.0301 & 65.8597 & 65.6079 & 65.4938 & 66.1380 \\
\hline Individual with low education level & 0.2316 & 0.4819 & - & - & - & - \\
\hline $\begin{array}{l}\text { Foreigner } \\
\text { Neighbourhood composition characteristics }\end{array}$ & - & - & 0.5498 & 0.2836 & - & - \\
\hline$\%$ of foreigners with low education level [per ha] & 0.1815 & 0.2248 & 0.2298 & 0.1821 & 0.2010 & 0.2534 \\
\hline$\%$ of foreigners with high education level [per ha] & 0.1804 & 0.1933 & 0.1797 & 0.1878 & 0.1738 & 0.1846 \\
\hline $\mathrm{N}$ & 26566 & 15596 & 13668 & 28494 & 6153 & 7515 \\
\hline
\end{tabular}

Note: The means that are statistically different between the two samples of each segment are highlighted in bold. Data sources: Swiss Population Census 2000, SITG, GIS-centre of the ARV, and Cantonal Offices of Protection against Noise of Geneva and Zurich.

\subsection{Housing conditions in Zurich}

For Zurich, we performed the same segmentations as for Geneva, i.e. based on the origin, the education attainment, and the origin of individuals with low education level. The results are presented in Table 7 , with the means that are statistically different between the two samples of each segment again highlighted in bold.

Considering first the segmentation by origin, reported in columns 2 and 3, we observe as in Geneva that Swiss people in Zurich live in comparatively larger dwellings in terms of number of rooms and surface per person. As in Geneva, we observe that Swiss people occupy dwellings of comparatively higher standard and that more of them have been living in the same dwelling for at least 5 years. Concerning the neighbourhood and environmental variables, the foreigners live on average in neighbourhoods with a higher population density, populated by a relatively higher proportion of foreigners, and are exposed on average to a higher road traffic noise level. 
Table 7. Statistics by origin and level of education of the household head for Zurich

\begin{tabular}{|c|c|c|c|c|c|c|}
\hline \multirow{2}{*}{$\begin{array}{l}\text { Segmentation } \\
\text { Sample }\end{array}$} & \multicolumn{2}{|c|}{ Origin } & \multicolumn{2}{|c|}{ Education } & \multicolumn{2}{|c|}{ Origin and education } \\
\hline & Swiss & Foreigner & $\begin{array}{l}\text { Low } \\
\text { education }\end{array}$ & $\begin{array}{l}\text { High } \\
\text { education }\end{array}$ & $\begin{array}{l}\text { Swiss: } \\
\text { Low education }\end{array}$ & $\begin{array}{l}\text { Foreigner: } \\
\text { Low education }\end{array}$ \\
\hline $\begin{array}{l}\text { Net monthly rent } \\
\text { Structural characteristics }\end{array}$ & 1232 & 1187 & 1000 & 1296 & 976 & 1033 \\
\hline Built between 1946 and 1960 & 0.2015 & 0.2092 & 0.2239 & 0.1965 & 0.2287 & 0.2173 \\
\hline Built between 1961 and 1970 & 0.1357 & 0.1417 & 0.1669 & 0.1271 & 0.1698 & 0.1629 \\
\hline Built between 1971 and 1980 & 0.1416 & 0.1105 & 0.1803 & 0.1179 & 0.2279 & 0.1145 \\
\hline Built between 1981 and 1990 & 0.0548 & 0.0626 & 0.0416 & 0.0619 & 0.0450 & 0.0370 \\
\hline Built between 1991 and 2000 & 0.0645 & 0.0714 & 0.0533 & 0.0706 & 0.0489 & 0.0594 \\
\hline Building was renovated before 1990 & 0.1803 & 0.1874 & 0.1706 & 0.1860 & 0.1595 & 0.1860 \\
\hline Floor level & 2.3101 & 19773 & 2.3921 & 2.1690 & 26577 & 2.0249 \\
\hline Number of floors in the building & 5.1769 & 4.9912 & 5.7024 & 4.9357 & 6.0044 & 5.2849 \\
\hline Number of rooms & 2.7946 & 2.6739 & 2.5079 & 2.8505 & 24318 & 2.6131 \\
\hline Surface per room [m2] & 26.1937 & 25.4112 & 26.1148 & 25.9539 & 26.9720 & 24.9297 \\
\hline Surface per inhabitant [m2] & 515979 & 38.1488 & 41.2690 & 50.5143 & 48.8747 & 30.7528 \\
\hline Kitchenette & 0.0141 & 0.0315 & 0.0261 & 0.0159 & 0.0180 & 0.0373 \\
\hline Attic & 0.0515 & 0.0427 & 0.0382 & 0.0530 & 0.0414 & 0.0338 \\
\hline Gas heating & 0.3425 & 0.3448 & 0.3384 & 0.3447 & 0.3218 & 0.3613 \\
\hline Privately owned building & 0.5272 & 0.5292 & 0.4463 & 0.5553 & 0.4108 & 0.4954 \\
\hline Publicly owned building & 0.0851 & 0.0868 & 0.1410 & 0.0667 & 0.1479 & 0.1316 \\
\hline $\begin{array}{l}\text { In the dwelling for at least } 5 \text { years } \\
\text { Location characteristics }\end{array}$ & 0.5841 & 0.4944 & 0.6709 & 0.5242 & 0.7114 & 0.6149 \\
\hline Distance to nearest transportation stop [km] & 0.1373 & 0.1379 & 0.1410 & 0.1363 & 0.1415 & 0.1403 \\
\hline Distance to nearest park [km] & 0.1297 & 0.1339 & 0.1276 & 0.1318 & 0.1227 & 0.1345 \\
\hline Distance to city centre $[\mathrm{km}]$ & 3.0674 & 3.2090 & 3.3778 & 3.0105 & 3.3965 & 3.3520 \\
\hline $\begin{array}{l}\text { Population density [per ha] } \\
\text { Environmental characteristics }\end{array}$ & 1418499 & 154.8473 & 156.2333 & 141.4069 & 147.6258 & 168.1344 \\
\hline $\begin{array}{l}\text { Daytime noise }[\mathrm{dB}(\mathrm{A})] \\
\text { Household head characteristics }\end{array}$ & 67.5623 & 67.8132 & 67.7227 & 67.5948 & 67.4803 & 68.0370 \\
\hline Individual with low education level & 0.1969 & 0.4172 & - & - & - & - \\
\hline $\begin{array}{l}\text { Foreigner } \\
\text { Neighbourhood composition characteristics }\end{array}$ & - & - & 0.4197 & 0.1985 & - & - \\
\hline$\%$ of foreigners with low education level [per ha] & 0.1167 & 0.1755 & 0.1786 & 0.1157 & 0.1412 & 0.2304 \\
\hline$\%$ of foreigners with high education level [per ha] & 0.1347 & 0.1559 & 0.1350 & 0.1418 & 0.1268 & 0.1462 \\
\hline $\mathrm{N}$ & 19749 & 6740 & 6700 & 19789 & 3888 & 2812 \\
\hline
\end{tabular}

Note: The means that are statistically different between the two samples of each segment are highlighted in bold. Data sources: Swiss Population Census 2000, SITG, GIS-centre of the ARV, and Cantonal Offices of Protection against Noise of Geneva and Zurich.

The second segmentation relates to the level of education of the households and is presented in columns 4 and 5 of Table 7. The same pattern observed for Geneva appears in Zurich between the dwellings inhabited by the low vs. the high educated individuals: on average household heads with low education level live in relatively smaller dwellings (in terms of surface per room and occupation rate of the dwelling surface) and of relatively lower standard. On average 14 per cent of the individuals with low education live in publicly owned building, while only 7 per cent of them live in private-owned buildings.

Finally, as reported in the last columns of Table 7, the segmentation between foreigners and Swiss with low education level shows a similar pattern as the one between low and high educated individuals. 


\section{Conclusion}

In this paper, we performed pairwise comparisons of housing conditions between Swiss and foreign residents, between high and low education individuals and between Swiss and foreign residents with low education. First we tested whether these groups mingle uniformly over the territories of the canton of Geneva and the city of Zurich. Not surprisingly, they do not, but the dissimilarity indices are relatively small. Even measured on a fine hectare grid, they do not exceed 40 per cent, the highest segregation being that of low education foreigners, who are actually more segregated from low education Swiss than high education Swiss and foreigners. Exposure indices indicate that residents with high education level are most concentrated, closely followed by high education Swiss. All these indices are very similar in Geneva and Zurich.

We pursued the pairwise comparisons on a large number of descriptors of dwellings and neighbourhoods. Of course, it is not always obvious to relate a descriptor to 'quality' or 'comfort'. Nevertheless, there emerges a picture, both in Geneva and Zurich, where foreigners, individuals with a low level of education, and particularly foreigners with low education attainment live in dwellings of relatively lesser quality on average as compared respectively to the Swiss, high educated and Swiss with low education level. This result is in accordance with Arend (1991) and Wanner (2004), who found that among foreigners, some might be particularly discriminated, since they live in dwellings of poor condition, underequipped, and even exposed to excessive air and noise nuisances.

We should however emphasize that differences in housing conditions do not necessary imply discrimination. Indeed, households living in dwellings of comparatively lower quality could be compensated through lower rents. In that case, they enjoy lesser comfort because they chose or were forced to spend less for it. At first glance, this does not appear to be the case of the foreigners with a low education level since both in Geneva and Zurich they pay on average a higher monthly rent than the Swiss with low education: 5.8 per cent more in Zurich and even 6.5 per cent more in Geneva. That hints at discrimination. In fact, there might even be discrimination between two groups when the group enjoying lesser comfort on average, say group $Y$, also pays less rent on average. That would be the case if the rent compensation for group $Y$ members is less than what the group $X$ members get who also occupy dwellings of lesser comfort.

Obviously, a formal model relating residential quality to price is necessary in order to identify discrimination on the housing market, i.e. whether members of some pay a higher price than those of another group for dwellings possessing the same characteristics. Such a model based on the hedonic price approach has been estimated in two companion papers by Baranzini et al. (2008) and Schaerer et al. (2008). They found that foreigners are discriminated against in the Geneva housing market, while in Zurich there is evidence of discrimination against individuals with a lower education level. 


\section{References}

Arend, M. (1991): "Housing segregation in Switzerland." In: Huttman, E.D. (ed.), Urban housing segregation of minorities in Western Europe and the United States, Durham and London: Duke University Press.

Arend, M., Kellerhals Spitz, A., Mächler, T. (1990): "Groupes défavorisés sur le marché du logement : Problèmes et mesures." Bulletin du logement 45, Office fédéral du logement, Bern, Switzerland.

Baranzini, A., Schaerer, C., Ramirez, J., Thalmann, P. (2008): "Do Foreigners Pay Higher Rents for the Same Quality of Housing in Geneva and Zurich?" Forthcoming, Swiss Journal of Economics and Statistics.

Baranzini, A., Schaerer, C., Ramirez, J., Thalmann, P. (2006): "Feel it or Measure it. Perceived vs. Measured Noise in Hedonic Models." Cahier de recherche HES-SO/HEG-GE/C-06/7/1-CH, Haute École de Gestion, Geneva, Switzerland, available at SSRN : http://ssrn.com/abstract=937259.

Bell W. (1954) "A probability model for the measurement of ecological segregation." Social Forces, 43: 357-364.

Duncan, O., Duncan, B. (1955): "Methodological analysis of segregation indexes." American Sociological Review, 20: 210-217.

Glaeser, E.L., Vigdor, J.L. (2001): "Racial segregation in the 2000 census: Promising news." Center on Urban and Metropolitan Policy, The Brookings Institution, Survey Series, Washington, DC.

Harrison, M., Law, I., Phillips, D. (2005): "Migrants, Minorities and Housing: Exclusion, Discrimination and Anti-Discrimination in 15 Member States of the European Union." European Monitoring Centre on Racism and Xenophobia, Vienna, Austria.

Heye, C., Leuthold, H. (2004): "Segregation und Umzüge in der Stadt und agglomeration Zürich." Gruppe sotomo, Geographisches Institut Universität Zürich.

Huissoud, T., Stofer, S., Cunha, A., Schuler, M. (1999): "Structures et tendances de la différenciation dans les espaces urbains en Suisse. "Rapport de recherche no 145, Institut de recherche sur l'environnement construit, EPFL, Lausanne, Switzerland.

Huissoud, T., Stofer, S., Cunha, A. (1999a): "L'influence régionale sur la répartition spatiale des populations." In : Structures et tendances de la différenciation dans les espaces urbains en Suisse. Rapport de recherche no 145, Partie II, Institut de recherche sur l'environnement construit, EPFL, Lausanne, Switzerland.

Huttman, E.D. (1991): "Housing Segregation in Western Europe: An Introduction." In: Huttman, E.D, Blauw W., Saltman, J. (eds.), Urban Housing Segregation of minorities in Western Europe and the United States, Durham and London: Duke University Press.

Massey D.S., Denton N.A. (1988): "The dimensions of racial segregation." Social Forces, 67: 281-315.

Miedema, H.M.E., Vos, H. (1998): "Exposure-response relationships for transportation noise." Journal of the Acoustical Society of America, 104(6): 3432-3445.

Miedema, H.M.E., Oudshoorn, C.G.M. (2001): "Annoyance from transportation noise: Relationships with exposure metrics DNL and DENL and their confidence interval." Environmental Health Perspectives, 109(4): 409-416

Myers, C.K. (2004): "Discrimination and neighbourhood effects: Understanding racial differentials in US housing prices." Journal of urban economics, 56: 279-302.

Office cantonal de la population (OCSTAT) (2005): "Portrait statistique des étrangers vivant à Genève: Résultats du recensement fédéral de la population et autres sources." Etudes et documents 37, Geneva, Switzerland.

Office fédéral de la statistique (OFS) (2006): "La population étrangère en Suisse." Série Statistique de la Suisse, OFS, Neuchâtel, Switzerland.

Omer I., Benenson I. (2002) "Investigating fine-scale residential segregation by means of local spatial statistics." Geography Research Forum, 12:41-60 
Parkinson, M., Moores, J., Champion, T., Simmie, J., Turok, I., Crookston, M., Katz, B., Park, A. (2006): "State of the English Cities." A Research Study, Vol. 1, Office of the Deputy Prime Minister, London, UK.

Reardon S.F., Firebaugh G. (2002) "Measures of multigroup segregation." Sociological Methodology, 32: 33-67.

Reardon S.F., O'Sullivan D. (2004) "Measures of spatial segregation." Sociological Methodology, 34: 121-162.

Schaerer, C., Baranzini, A., Ramirez, J.V., Thalmann, P. (2008): "Assessing the impacts of discrimination and prejudice in the Geneva and Zurich housing markets." Cahier de recherche HESSO/HEG-GE, Haute École de Gestion, Geneva, Switzerland.

Schuler, M. (1999): "La différenciation selon les types communaux." In : Structures et tendances de la différenciation dans les espaces urbains en Suisse. " Rapport de recherche no 145, Partie VII, Institut de recherche sur l'environnement construit, EPFL, Lausanne, Switzerland.

Schuler, M., Huissoud, T. (1999): "La différenciation dans une optique temporelle." In: Structures et tendances de la différenciation dans les espaces urbains en Suisse. Rapport de recherche no 145, Partie VI, Institut de recherche sur l'environnement construit, EPFL, Lausanne, Switzerland.

Swiss Noise Abatement Ordinance (1986). SR 814.41. AS 1987 338. Bern, Switzerland.

Wanner, P. (2004): "Migration et intégration: Populations étrangères en Suisse." Office fédéral de la statistique, Neuchâtel, Switzerland.

Wong D.W.S. (2003): "Implementing spatial segregation measures in GIS." Computers, Environment and Urban Systems, 27: 53-70.

Wong D.W.S. (2008): "Conceptual and Operational Issues in Incorporating Segregation Measurements in Hedonic Price Modeling." In: Baranzini A., Ramirez J., Schaerer C., Thalmann P. (eds.), Hedonic Methods in Housing Markets. Pricing Environmental Amenities and Segregation, New York: Springer. 


\section{Cahiers de recherche du Centre de Recherche Appliquée en Gestion (CRAG) de la Haute Ecole de Gestion - Genève}

\section{(C) 2006}

CRAG - Centre de Recherche Appliquée en Gestion

Haute école de gestion - Genève

Campus de Battelle, Bâtiment $\mathrm{F}$

7, route de Drize - 1227 Carouge - Suisse

$\triangle$ crag@hesge.ch

www.hesge.ch/heg/crag

(d) +41223881818

圆 +41223881740

\section{6}

- $\quad \mathrm{N}^{\circ} \mathrm{HES}-\mathrm{SO} / \mathrm{HEG}-\mathrm{GE} / \mathrm{C}--06 / 1 / 1--\mathrm{CH}$

Andrea BARANZINI

Damien ROCHETTE

"La demande de récréation pour un parc naturel. Une application au Bois de Pfyn-

Finges, Suisse"

- $\quad \mathrm{N}^{\circ} \mathrm{HES}-\mathrm{SO} / \mathrm{HEG}-\mathrm{GE} / \mathrm{C}--06 / 2 / 1--\mathrm{CH}$

Giovanni FERRO LUZZI

Yves FLÜCKIGER

Sylvain WEBER

"A Cluster Analysis of Multidimentional Poverty in Switzerland"

- $\quad \mathrm{N}^{\circ} \mathrm{HES}-\mathrm{SO} / \mathrm{HEG}-\mathrm{GE} / \mathrm{C}--06 / 3 / 1--\mathrm{CH}$

Giovanni FERRO LUZZI

Sylvain WEBER

"Measuring the Performance of Microfinance Institutions"

- $\quad \mathrm{N}^{\circ} \mathrm{HES}-\mathrm{SO} / \mathrm{HEG}-\mathrm{GE} / \mathrm{C}--06 / 4 / 1--\mathrm{CH}$

Jennifer D'URSO

"L'eau de boisson : Aspects logistiques et attitude du consommateur"

- $\quad \mathrm{N}^{\circ} \mathrm{HES}-\mathrm{SO} / \mathrm{HEG}-\mathrm{GE} / \mathrm{C}--06 / 5 / 1--\mathrm{CH}$

Jennifer D'URSO

"La gestion publique de l'eau en Suisse"

- $\quad \mathrm{N}^{\circ} \mathrm{HES}-\mathrm{SO} / \mathrm{HEG}-\mathrm{GE} / \mathrm{C}--06 / 6 / 1-\mathrm{CH}$

Philippe THALMANN

Andrea BARANZINI

"Gradual Introduction of Coercive Instruments in Climate Policy" 
- $\quad \mathrm{N}^{\circ} \mathrm{HES}-\mathrm{SO} / \mathrm{HEG}-\mathrm{GE} / \mathrm{C}--06 / 7 / 1--\mathrm{CH}$

Andrea BARANZINI

Caroline SCHAERER

José RAMIREZ

Philippe THALMANN

"Feel it or Measure it. Perceived vs. Measured Noise in Hedonic Models"

- $\quad N^{\circ}$ HES-SO/HEG-GE/C--06/8/1--CH

José RAMIREZ

Anatoli VASSILIEV

"An Efficiency Comparison of Regional Employment Offices Operating under Different Exogenous Conditions"

- $\quad \mathrm{N}^{\circ} \mathrm{HES}-\mathrm{SO} / \mathrm{HEG}-\mathrm{GE} / \mathrm{C}--06 / 9 / 1--\mathrm{CH}$

José RAMIREZ

Joseph DEUTSCH

Yves FLÜCKIGER

Jacques SILBER

"Export Activity and Wage Dispersion : The Case of Swiss Firms"

- $\quad N^{\circ}$ HES-SO/HEG-GE/C--06/10/1--CH

Joëlle DEBELY

Gaëtan DERACHE

Emmanuel FRAGNIERE

Jean TUBEROSA

"Rapport d'enquête : sondage Infobésité"

- $\quad N^{\circ} \mathrm{HES}-\mathrm{SO} / \mathrm{HEG}-\mathrm{GE} / \mathrm{C}--06 / 11 / 1--\mathrm{CH}$

Andrea BARANZINI

José RAMIREZ

Cristian UGARTE ROMERO

"Les déterminants du choix de (dé)localisation des entreprises en Suisse"

- $\quad N^{\circ} \mathrm{HES}-\mathrm{SO} / \mathrm{HEG}-\mathrm{GE} / \mathrm{C}--06 / 12 / 1--\mathrm{CH}$

Catherine EQUEY BALZLI

Jean TUBEROSA

David MARADAN

Marie-Eve ZUFFEREY BERSIER

"Étude du comportement des PME/PMI suisses en matière d'adoption de système de gestion intégré. Entre méconnaissance et satisfaction."

- $\quad N^{\circ}$ HES-SO/HEG-GE/C--06/13/1--CH

Joëlle DEBELY

Magali DUBOSSON

Emmanuel FRAGNIÈRE

"The pricing of the knowledge-based services : Insight from the environmental sciences" 
- $\quad \mathrm{N}^{\circ} \mathrm{HES}-\mathrm{SO} / \mathrm{HEG}-\mathrm{GE} / \mathrm{C}-\mathrm{-07/1/1-- \textrm {CH }}$

Andrea BARANZINI

Caroline SCHAERER

"A Sight for Sore Eyes

Assessing the value of view and landscape use on the housing market"

- $\mathrm{N}^{\circ} \mathrm{HES}-\mathrm{SO} / \mathrm{HEG}-\mathrm{GE} / \mathrm{C}--07 / 2 / 1-\mathrm{CH}$

Joëlle DEBELY

Magali DUBOSSON

Emmanuel FRAGNIÈRE

"The Travel Agent: Delivering More Value by Becoming an Operational Risk

Manager"

- $\quad N^{\circ}$ HES-SO/HEG-GE/C--07/3/1--CH

Joëlle DEBELY

Magali DUBOSSON

Emmanuel FRAGNIÈRE

"The Consequences of Information Overload in Knowledge Based Service

Economies"

- $\quad \mathrm{N}^{\circ} \mathrm{HES}-\mathrm{SO} / \mathrm{HEG}-\mathrm{GE} / \mathrm{C}--07 / 4 / 1--\mathrm{CH}$

Lucie BEGIN

Jacqueline DESCHAMPS

Hélène MADINIER

"Une approche interdisciplinaire de l'intelligence économique"

- $\quad \mathrm{N}^{\circ} \mathrm{HES}-\mathrm{SO} / \mathrm{HEG}-\mathrm{GE} / \mathrm{C}-\mathrm{-} 07 / 5 / 1--\mathrm{CH}$

Journée de la recherche HEG 2007

"Recueil des communications"

- $\quad \mathrm{N}^{\circ} \mathrm{HES}-\mathrm{SO} / \mathrm{HEG}-\mathrm{GE} / \mathrm{C}--07 / 6 / 1--\mathrm{CH}$

Sylvain WEBER

Andrea BARANZINI

Emmanuel FRAGNIÈRE

"Consumers Choices among Alternative Electricity Programs in Geneva - An

Empirical Analysis"

2008

- $\quad \mathrm{N}^{\circ} \mathrm{HES}-\mathrm{SO} / \mathrm{HEG}-\mathrm{GE} / \mathrm{C}-\mathrm{-08} / 1 / 1-\mathrm{-CH}$

Andrea BARANZINI

José RAMIREZ

Sylvain WEBER

"The Demand for Football in Switzerland : An Empirical Estimation" 
- $\quad \mathrm{N}^{\circ} \mathrm{HES}-\mathrm{SO} / \mathrm{HEG}-\mathrm{GE} / \mathrm{C}-\mathrm{-0} / 2 / 1--\mathrm{CH}$

Giuseppe CATENAZZO

Gaëtan DERACHE

Emmanuel FRAGNIÈRE

Patricia HUGENTOBLER

Jean TUBEROSA

"Rapport d'enquête préliminaire : Dessine-moi un service ! Entreprises et administration : comment concevoir et valoriser vos services"

- $\mathrm{N}^{\circ} \mathrm{HES}-\mathrm{SO} / \mathrm{HEG}-\mathrm{GE} / \mathrm{C}-\mathrm{-08/3/1--CH}$

Nguyen VI CAO

Emmanuel FRAGNIÈRE

Jacques-Antoine GAUTHIER

Marlène SAPIN

Eric WIDMER

"Optimizing the marriage market through the reallocation of partners : An application of the linear assignment model"

- $\quad \mathrm{N}^{\circ}$ HES-SO/HEG-GE/C--08/4/1--CH

Magali DUBOSSON

Emmanuel FRAGNIÈRE

Bernard MILLIET

"A Control System Designed to Address the Intangible Nature of Service Risks"

- $\quad \mathrm{N}^{\circ}$ HES-SO/HEG-GE/C--08/5/1--CH

Giuseppe CATENAZZO

Jennifer D'URSO

Emmanuel FRAGNIÈRE

Jean TUBEROSA

"Influences of Public Ecological Awareness and Price on Potable Water Consumption in the Geneva Area"

- $\quad \mathrm{N}^{\circ} \mathrm{HES}-\mathrm{SO} / \mathrm{HEG}-\mathrm{GE} / \mathrm{C}--08 / 6 / 1--\mathrm{CH}$

Alexandra BROILLET

Magali DUBOSSON

"Analyzing Web 2.0 Internet users in order to drive innovation in distribution strategy of luxury watches : A netnography analysis"

- $\mathrm{N}^{\circ} \mathrm{HES}-\mathrm{SO} / \mathrm{HEG}-\mathrm{GE} / \mathrm{C}-\mathrm{-08/7/2-- \textrm {CH }}$

Alexandra BROILLET

Magali DUBOSSON

"Luxury e-services at the pre- and after-sales stages of the decision making process:

Watch, car, art and travel blogs analysis"

- $\quad \mathrm{N}^{\circ} \mathrm{HES}-\mathrm{SO} / \mathrm{HEG}-\mathrm{GE} / \mathrm{C}--08 / 8 / 1--\mathrm{CH}$

Nicolas BUGNON

René SCHEIDER

"OPACs et utilisateurs - L'étude ACUEIL démontre les comportements de recherche et propose des outils simplifiés et flexibles" 
- $\quad \mathrm{N}^{\circ} \mathrm{HES}-\mathrm{SO} / \mathrm{HEG}-\mathrm{GE} / \mathrm{C}-\mathrm{-08} / 9 / 1-\mathrm{CH}$

Giuseppe Catenazzo

Emmanuel Fragnière

"Attitudes Regarding New Enterprise Risk and Control Regulations by the Active Population of the Geneva Area"

- $\quad \mathrm{N}^{\circ} \mathrm{HES}-\mathrm{SO} / \mathrm{HEG}-\mathrm{GE} / \mathrm{C}--08 / 10 / 1--\mathrm{CH}$

\section{Giuseppe Catenazzo}

Emmanuel Fragnière

"Identifying Bank Runs Signals through Sociological Factors: An Empirical Research in the Geneva Area" 